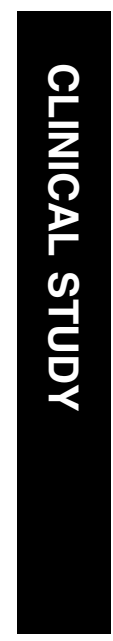

\title{
High-dose intravenous immunoglobulin in the treatment of toxic epidermal necrolysis: a study of ocular benefits
}

${ }^{1}$ The Eye Institute @ Tan Tock Seng Hospital National Healthcare Group Singapore

${ }^{2}$ Department of Rheumatology, Allergy and Immunology, Tan Tock Seng Hospital, Singapore

${ }^{3}$ National Skin Centre Singapore

${ }^{4}$ Clinical Trials \& Epidemiology Research Unit Ministry of Health Singapore

Correspondence: LW Yip

The Eye Institute

National Healthcare Group

Tan Tock Seng Hospital

11 Jalan Tan Tock Seng

Singapore 308433

Singapore

Tel: 6563577726

Fax: 6563577718

E-mail: leonard_yip@

ttsh.com.sg

Received: 8 March 2004 Accepted: 1 June 2004

Published online:

24 September 2004

Presented in part as a poster at the National Healthcare Group Annual Scientific Congress 2003, Singapore, 4-5 October 2003
Abstract

Purpose To compare acute ocular complications of toxic epidermal necrolysis (TEN) following treatment with high-dose human intravenous immunoglobulin (IVIG) with a historical cohort not treated with IVIG. Methods Retrospective, historically controlled study. In all, 10 consecutive patients with TEN (treatment cohort) presenting between 1 July 2001 and 30 June 2002. Totally, 18 consecutive patients with TEN (historical cohort).

Setting Tan Tock Seng Hospital, Singapore. The treatment cohort received high-dose IVIG ( $2 \mathrm{~g} / \mathrm{kg}$ body weight over 2 days). Patients' records were retrospectively reviewed for their demographic characteristics, causative drug, treatment, ocular involvement (if any, as assessed by an ophthamologist), and its severity. The historical cohort comprised patients coded with a diagnosis of TEN (ICD Code 695.1) between 1 July 1995 and 30 June 2001.

Results Nine $(\mathbf{9 0 \%})$ of 10 patients treated with IVIG had ocular involvement. Phenytoin was the implicated drug in three $(\mathbf{3 7 . 5 \%})$ patients. Of the nine patients, 1 died of septic shock. Of the eight survivors, IVIG was initiated immediately upon onset of TEN as all the patients were hospitalized by the time of onset of an exanthema. Acute ocular complications were mild in two (25\%) (lid oedema or mild conjunctival injection), moderate in four (50\%) (pseudomembranes) and severe in two (25\%) (nonhealing epithelial defect with visual loss and symblepharon). In total, $10(55.6 \%)$ of 18 patients in the historical cohort with TEN had acute ocular
LW Yip", BY Thong², AW Tan³, L-W Khin ${ }^{4}$ $\mathrm{H}-\mathrm{H} \mathrm{Chng}^{2}$ and $\mathrm{W}$-J Heng involvement. Two patients died. Ocular involvement in survivors was mild in five $(62.5 \%)$ cases and moderate in three $(37.5 \%)$, with no severe cases.

Conclusions IVIG did not appear to reduce the severity of visually significant ocular complications. Larger studies are needed to confirm this finding.

Eye (2005) 19, 846-853. doi:10.1038/sj.eye.6701653; published online 24 September 2004

Keywords: intravenous immunoglobulins; toxic epidermal necrolysis; ocular complications

Introduction

Toxic epidermal necrolysis (TEN) is a severe acute drug-induced condition characterised by skin denudation due to separation at the dermoepidemal junction. Ocular and orogenital mucous membranes may also be involved, as in Stevens-Johnson syndrome (SJS). The mortality from TEN in large studies ranged from 25 to $34 \% .^{1,2}$ There is a paucity of literature on the prevalence, effects of immunomodulatory therapies and outcomes of ocular complications of SJS/TEN. Ocular complications may occur acutely, together with or after the onset of skin denudation. Although relatively uncommon, ocular complications may result in permanent visual loss. Ocular involvement may go undiagnosed and hence, eye care often overlooked in the management of patients with TEN. No systemic treatment, including systemic corticosteroids, ${ }^{3}$ have to date been conclusively shown to have an effect on the incidence or severity of ocular involvement.

Novel immunomodulatory therapies for SJS/ TEN have emerged due to 
immunohistochemical studies of skin lesions which suggest a role for drug-specific T cells in maculopapular, bullous and pustular skin reactions, in particular, Tlymphocyte cytotoxicity mediated via perforin/ granzyme B and death receptors like Fas/Fas ligand. ${ }^{4}$ The rationale for the use of IVIG is based on the inhibition of Fas-mediated keratinocyte apoptosis in TEN by naturally occurring Fas-blocking antibodies within the IVIG. ${ }^{5}$ Studies on the use of IVIG in $\mathrm{TEN}^{5-9}$ have so far focused on cutaneous outcomes, including some reports of reduction in mortality rates, with none reporting specifically on the effects on ocular outcomes. In SJS, the severity of systemic involvement is reported to be a factor that determines late ocular complications. ${ }^{10}$ Thus, a treatment that modifies the severity of systemic disease in TEN may potentially prove beneficial in reducing ocular complications.

In this study, we describe the acute ocular manifestations and outcomes of TEN in a consecutive series of patients treated with IVIG and compare them with a historical cohort not treated with IVIG.

\section{Materials and methods}

This retrospective study was approved by the Tan Tock Seng Hospital Ethics Committee. Consecutive patients admitted to Tan Tock Seng Hospital during the study period $1^{\text {st }}$ July, 2001 to $30^{\text {th }}$ June, 2002 with the diagnosis of TEN and treated with IVIG were included. The classification criteria by Bastuji-Garin et $a l^{11}$ was used to define TEN, namely, epidermal detachment involving more than $30 \%$ of body surface area. The diagnosis was verified by a dermatologist or a clinical immunologist/ allergist. All patients were treated with high-dose IVIG $2 \mathrm{~g} / \mathrm{kg}$ body weight given over 2 consecutive days if renal function was normal. Patients' records were retrospectively reviewed for their demographic characteristics, causative drug, treatment, adverse events, ocular involvement (if any, as assessed by an ophthamologist), and its severity.

Patients with clinical evidence of acute ocular complications were reviewed by an ophthalmologist to determine the type, extent, and severity of ocular involvement. The severity of acute ocular complications was graded as mild, moderate, or severe. This has previously been described by Power et al. ${ }^{3}$ Briefly, mild ocular involvement was defined as lid oedema and/or mild conjunctival injection and/or chemosis only. Moderate involvement was defined as membranous conjunctivitis and/or corneal epithelial defects more than $30 \%$ healing with medical treatment and/or corneal ulceration and/or corneal infiltrates. Severe involvement was defined as symblepharon formation and/or nonhealing corneal epithelial defects and/or visual loss and/or conjunctival fornix foreshortening. All patients were followed-up to 6 weeks to assess for sequelae of acute ocular complications.

A historical cohort was obtained from patients coded with a diagnosis of TEN (ICD Code 695.1) from admissions to Tan Tock Seng Hospital between 1 July, 1995 and 30 June, 2001. Only data of surviving patients in both groups were used in the analysis. This was to try to avoid differential misclassification.

The data were analysed using SPSS statistical software (Version 11.5) (Chicago, IL, USA). Proportions (\%) were used to describe categorical variables and $\chi^{2}$ test and Fisher's exact test used to assess differences between groups. As for continuous variables, results are presented as mean \pm SD. Nonparametric assumption was made because of the not normal distributions and small sample size. The differences in mean age were compared using the Mann-Whitney U test. P-values of less than 0.05 were considered statistically significant.

\section{Results}

In all, 10 patients were diagnosed with TEN, of whom, nine $(90.0 \%)$ had ocular involvement. Of these nine patients, one patient with more than $80 \%$ skin involvement, died of septic shock from Pseudomonas aeruginosa bacteraemia despite having IVIG started 4 days after onset of TEN. Only the surviving eight patients with ocular involvement who could be followedup beyond 6 weeks are described.

The patients' characteristics, implicated drugs, acute ocular complications, and treatment given are presented in Table 1 . The mean age of the patients was $54.6 \pm 19.9$ years (range, 19-70 years). There were seven Chinese and one Malay patient and an equal number of males and females. The mean follow-up duration by the ophthalmologist was $10.3 \pm 6.9$ months (range, 1.5-19 months). The mean duration between the onset of an exanthema and TEN was $8.1 \pm 5.7$ days (range, 3-20 days). The causative drugs were phenytoin in three cases, and cotrimoxazole, allopurinol, omeprazole, acyclovir, and traditional Malay medication adulterated with phenylbutazone in each of the remaining cases. All except one patient with intercurrent infection received systemic corticosteroids (equivalent to prednisolone $1 \mathrm{mg} / \mathrm{kg}$ body weight per day) prior to the onset of TEN. However, upon onset of TEN, systemic corticosteroids were stopped and high-dose IVIG initiated. As these patients were all hospitalized by the time of onset of the exanthem, high-dose IVIG could be started immediately upon onset of TEN. Upon cessation of IVIG, a decremental dose of systemic corticosteroids was continued in three patients over a period of 7-28 days. All the patients had normal baseline serum creatinine 
Table 1 Treatment group patient characteristics, putative drugs, acute ocular complications, and treatment

\begin{tabular}{|c|c|c|c|c|c|c|c|c|c|c|c|c|c|}
\hline No & Age & Sex & Race & Drug aetiology & $\begin{array}{c}\text { Duration } \\
\text { between onset } \\
\text { of exanthem } \\
\text { and TEN } \\
\text { (days) }\end{array}$ & $\begin{array}{l}\text { Ocular } \\
\text { involvement } \\
\text { at onset of } \\
\text { exanthem }\end{array}$ & $\begin{array}{c}\text { Duration of } \\
\text { hospitalisation } \\
\text { (days) }\end{array}$ & $\begin{array}{l}\text { Acute ocular } \\
\text { complications }\end{array}$ & $\begin{array}{l}\text { Severity of } \\
\text { acute ocular } \\
\text { complications }\end{array}$ & $\begin{array}{l}\text { Pre-IVIG } \\
\text { systemic } \\
\text { corticosteroids }\end{array}$ & $\begin{array}{l}\text { Post-IVIG } \\
\text { systemic } \\
\text { corticosteroids }\end{array}$ & Other treatments & $\begin{array}{l}\text { Follow-up } \\
\text { duration } \\
\text { (months) }\end{array}$ \\
\hline 1 & 69 & Male & Chinese & Omeprazole & 20 & No & 29 & $\begin{array}{l}\text { Lid swelling, } \\
\text { conjunctival } \\
\text { injection, } \\
\text { pseudomembranes }\end{array}$ & Moderate & Yes & No & $\begin{array}{l}\text { Systemic steroids, } \\
\text { topical steroids, } \\
\text { topical antibiotics, } \\
\text { topical lubricants }\end{array}$ & 1.5 \\
\hline 2 & 64 & Male & Chinese & Co-trimoxazole & 3 & No & 23 & $\begin{array}{l}\text { Conjunctival } \\
\text { injection, } \\
\text { pseudomembranes }\end{array}$ & Moderate & Yes & Yes & $\begin{array}{l}\text { Systemic steroids, } \\
\text { topical steroids, } \\
\text { topical antibiotics, } \\
\text { topical lubricants }\end{array}$ & 6 \\
\hline 3 & 19 & Female & Malay & Aciclovir & 3 & Yes & 33 & $\begin{array}{l}\text { Conjunctival } \\
\text { injection, } \\
\text { pseudomembranes, } \\
\text { symblepharon, } \\
\text { nonhealing corneal } \\
\text { epithelial loss and } \\
\text { ulceration, }\end{array}$ & Severe & No & No & $\begin{array}{l}\text { Topical steroids, } \\
\text { topical antibiotics, } \\
\text { topical lubricants, } \\
\text { fornix sweeping, } \\
\text { amniotic membrane } \\
\text { transplant }\end{array}$ & e \\
\hline 4 & 29 & Male & Chinese & Phenytoin & 4 & No & 12 & $\begin{array}{l}\text { Conjunctival } \\
\text { injection, } \\
\text { pseudomembranes }\end{array}$ & Moderate & Yes & No & $\begin{array}{l}\text { Systemic steroids, } \\
\text { topical steroids, } \\
\text { topical antibiotics, } \\
\text { topical lubricants }\end{array}$ & 9 \\
\hline 5 & 65 & Female & Chinese & Allopurinol & 11 & No & 21 & $\begin{array}{l}\text { Conjunctival } \\
\text { injection }\end{array}$ & Mild & Yes & No & $\begin{array}{l}\text { Systemic steroids, } \\
\text { topical steroids, } \\
\text { topical antibiotics, } \\
\text { topical lubricants }\end{array}$ & 13 \\
\hline 6 & 70 & Male & Chinese & Phenytoin & 10 & No & 14 & Lid swelling & Mild & Yes & Yes & $\begin{array}{l}\text { Systemic steroids, } \\
\text { topical antibiotics, } \\
\text { topical lubricants }\end{array}$ & 1.5 \\
\hline 7 & 52 & Female & Chinese & Phenylbutazone & 8 & Yes & 21 & $\begin{array}{l}\text { Conjunctival } \\
\text { injection, } \\
\text { pseudomembranes, } \\
\text { symblepharon, } \\
\text { corneal epithelial } \\
\text { loss healing with } \\
\text { medical treatment, }\end{array}$ & Severe & Yes & Yes & $\begin{array}{l}\text { Systemic steroids, } \\
\text { topical steroids, } \\
\text { topical antibiotics, } \\
\text { topical lubricants, } \\
\text { fornix sweeping }\end{array}$ & 14 \\
\hline 8 & 68 & Female & Chinese & Phenytoin & 6 & No & 10 & $\begin{array}{l}\text { Lid swelling, } \\
\text { conjunctival } \\
\text { injection, } \\
\text { pseudomembranes }\end{array}$ & Moderate & Yes & No & $\begin{array}{l}\text { Systemic steroids, } \\
\text { topical steroids, } \\
\text { topical antibiotics, } \\
\text { topical lubricants }\end{array}$ & 18 \\
\hline
\end{tabular}

as assessed by the dermatologist or allergist-immunologist. 
( $<140 \mu \mathrm{mol} / 1)$ prior to IVIG infusion. All except one patient had topical steroid treatment. All patients received both topical antibiotics (eyedrops and ointment) and lubricants. The IVIG therapy was well tolerated in all patients with no adverse events.

The ocular outcomes of the eight patients were as follows. Two patients had mild ocular involvement with lid oedema or mild conjunctival injection only. Four patients had moderate ocular complications with pseudomembrane formation in addition to conjunctival injection. Two patients had severe ocular involvement. One had pseudomembranes, symblepharon formation requiring fornix sweeping and a small corneal epithelial defect which healed with topical medical treatment. There was no visual loss. The other patient had a persistent nonhealing epithelial defect in one eye that finally required an amniotic membrane graft to aid healing. At last follow-up 19 months after the acute event, this eye had severe peripheral vascularisation and scarring of the cornea resulting in a visual acuity of hand motion. One patient had visual acuity of 20/80 in one eye due to a hemi-retinal vein occlusion 6 months later, unrelated to the original problem. The other six patients with mild-to-moderate ocular involvement did not suffer visual loss as a result of the TEN up to 6 weeks following the acute event. In summary, only one of the eight patients $(12.5 \%)$ had visually significant ocular complications which persisted beyond 6 weeks. There was no difference in the time between administration of high-dose IVIG and onset of TEN and severity of acute ocular involvement.
There were 18 cases from the historical cohort of which $10(55.6 \%)$ had acute ocular involvement verified by an ophthalmologist. Two of these patients died. The mean age of the patients was $53.3 \pm 17.5$ years (range, $28-75$

Table 3 Frequency of ocular complications among surviving patients: IVIG-treated patients compared with non-IVIG-treated patients

\begin{tabular}{lccl}
\hline $\begin{array}{l}\text { Ocular } \\
\text { complications }\end{array}$ & $\begin{array}{c}\text { Treatment } \\
\text { with IVIG } \\
(n=9)\end{array}$ & $\begin{array}{c}\text { Historical } \\
\text { cohort } \\
(n=15)\end{array}$ & P-value \\
\hline Yes & $8(88.9 \%)$ & $8(53.3 \%)$ & - \\
No & $1(11.1 \%)$ & $7(46.7 \%)$ & $\begin{array}{l}0.1782 \text { (Fisher's } \\
\text { exact probability } \\
\text { test) }\end{array}$ \\
\hline
\end{tabular}

n: number of patients in cohort; IVIG: intravenous immunoglobulins.

Table 4 Ocular complications among surviving patients with ocular complications by severity: IVIG-treated patients compared with non-IVIG-treated patients

\begin{tabular}{lccc}
\hline $\begin{array}{l}\text { Ocular } \\
\text { complications }\end{array}$ & $\begin{array}{c}\text { Treatment } \\
\text { with IVIG } \\
(n=8)\end{array}$ & $\begin{array}{c}\text { Historical } \\
\text { cohort }(n=8)\end{array}$ & $\begin{array}{c}\text { Power et al } \\
(n=30)\end{array}$ \\
\hline Mild & $2(25.0 \%)$ & $5(62.5 \%)$ & $12(40.0 \%)$ \\
Moderate & $4(50.0 \%)$ & $3(37.5 \%)$ & $10(33.0 \%)$ \\
Severe & $2(25.0 \%)$ & $0(0.0 \%)$ & $8(27.0 \%)$ \\
\hline
\end{tabular}

$\mathrm{n}$ : number of patients in cohort; IVIG: intravenous immunoglobulins; $P=0.1198$ (log-likelihood ratio test) (treatment and historical cohort comparison); $P=0.2282$ (log-likelihood ratio test) (three groups comparison).

Table 2 Characteristics of treatment group and historical cohort

\begin{tabular}{|c|c|c|c|}
\hline & Treatment group (IVIG) & Historical cohort & P-value \\
\hline Total cases found & 10 & 18 & \\
\hline Surviving number & 9 & 15 & \\
\hline $\begin{array}{l}\text { Number surviving with eye } \\
\text { complications }\end{array}$ & 8 & 8 & \\
\hline Mean age & $\begin{array}{l}54.6 \pm 19.9 \text { years } \\
\text { (range, } 19-70 \text { years) }\end{array}$ & $\begin{array}{l}53.3 \pm 17.5 \text { years } \\
\text { (range, } 28-75 \text { years) }\end{array}$ & $\begin{array}{l}(P=0.798 \\
\text { Mann-Whitney } \\
\text { U test })\end{array}$ \\
\hline Sex ratio & $1: 1$ & $1: 1$ & \\
\hline Race & $\begin{array}{l}\text { Seven Chinese, } \\
\text { one Malay }\end{array}$ & $\begin{array}{l}\text { six Chinese and } \\
\text { two Malays }\end{array}$ & \\
\hline $\begin{array}{l}\text { Number receiving systemic } \\
\text { steroids }\end{array}$ & $7(87.5 \%)$ & $5(62.5 \%)$ & $\begin{array}{l}(P=0.569, \text { Fisher's } \\
\text { exact test })\end{array}$ \\
\hline Causative drugs & $\begin{array}{l}\text { Phenytoin (3) } \\
\text { Acyclovir (1) } \\
\text { Allopurinol (1) } \\
\text { Cotrimoxazole (1) } \\
\text { Omeprazole (1) } \\
\text { Phenylbutazone (1) }\end{array}$ & $\begin{array}{l}\text { Cotrimoxazole (2) } \\
\text { Allopurinol (1) } \\
\text { Ampicillin/sulbactam } \\
\text { (1) } \\
\text { Frusemide (1) } \\
\text { Rifampicin (1) } \\
\text { Phenytoin (1) } \\
\text { Prochorperazine (1) }\end{array}$ & \\
\hline
\end{tabular}

IVIG : intravenous immunoglobulins. 
years). There were six Chinese and two Malay patients and an equal number of males and females. The mean follow-up duration by the ophthalmologist was $21.3 \pm 26.5$ months (range, $1-70$ months). The most common causative drug was cotrimoxazole in two cases. Five patients received systemic corticosteroids (equivalent to prednisolone $1 \mathrm{mg} / \mathrm{kg}$ body weight per day). Ocular involvement in the survivors was classified as mild in five $(62.5 \%)$ cases and moderate in three $(37.5 \%)$, with no severe cases.

The characteristics of surviving patients with eye complications, the implicated drugs and proportions treated with systemic corticosteroids are summarised for the treatment group and historical cohort in Table 2. The mean age difference between patients and their controls was not statistically significant $(P=0.798$ by MannWhitney $\mathrm{U}$ test). The proportion of patients receiving systemic steroids $(87.5 \%)$ was 1.4 times higher than that of controls $(62.5 \%)$, but this value did not reach a statistically significant level $(P=0.569$ by Fisher's exact probability test). The ratio of males to females was equal in both groups. There was no difference in the proportion of survivors with ocular complications between the treatment and historical cohorts. $(P=0.17818$ by Fisher's exact probability test) (Table 3 ). There was also no difference in the severity of visually significant ocular complications between the treatment and historical cohorts $(P=0.1198$ by log-likelihood ratio test) (Table 4$)$.

\section{Discussion}

There is a paucity of information on the prevalence and types of acute and long-term ocular complications related to TEN. A review of existing literature $\mathrm{e}^{1,7,12-15,16-18}$ showed the prevalence of acute ocular complications ranged from $6.1 \%(n=98)$ to $100.0 \%(n=17)$, and longterm sequelae from $1 \%(n=98)$ to $50 \%(n=87)$. The most common long-term sequelae was sicca syndrome ${ }^{19}$ (Table 5). There has been only one large, retrospective study looking specifically at acute ocular manifestations of TEN. Power $e t a l .^{3}$ reported severe acute ocular involvement in $27 \%$ of 30 patients with TEN. In all, $80 \%$ of those patients had a drug aetiology for their TEN, the most common being sulphonamides and aromatic anticonvulsants. Treatment modalities employed in their TEN patients were as follows: $100 \%$ received topical antibiotics, $47 \%$ topical corticosteroids, $57 \%$ lubricants, and $33 \%$ had fornix sweeping. They found no effect of systemic corticosteroids on the severity of ocular involvement. In the Revuz $e t a l^{20}$ report, the acute eye management of their patients consisted of daily examination of patients and institution of antibiotic and/ or antiseptic eye drops 10-24 times daily. Synechiae was noted to form during the second week, requiring separation at least four times daily using a blunt instrument. Up to 3 months following the acute event, common ocular complications reported included corneal ulceration, corneal epithelial defect, symblepharon and fornix foreshortening, ${ }^{3}$ and sicca syndrome. ${ }^{1}$

Several case series have described the benefit of intravenous pooled immunoglobulin (IVIG) in reducing the mortality rate in both adult and paediatric patients. The largest therapeutic study of IVIG in TEN to date is a retrospective multicentre study of 48 patients, which showed that survivors had received earlier treatment (mean of $6.8 \pm 6.1$ days in survivors compared to $10.2 \pm 4.3$ days in nonsurvivors) with a higher total dose of IVIG (mean of $2.8 \pm 1.0 \mathrm{~g} / \mathrm{kg}$ in survivors compared to $2.0 \pm 0.6 \mathrm{~g} / \mathrm{kg}$ in nonsurvivors), and had fewer chronic comorbidities including renal, cardiovascular, malignant, and infectious disease. Mucosal lesions responded in a manner similar to the cutaneous lesions after IVIG treatment with no ocular or mucous sequelae 45 days from onset of TEN. ${ }^{7}$ However, a prospective open trial of high-dose IVIG (total dose $2 \mathrm{~g} / \mathrm{kg}$ body weight) in 34 consecutive patients with SJS (nine cases), SJS-TEN (five cases) and TEN (20 cases) showed no effect on the progression of epidermolysis or any significant reduction in mortality, especially in the elderly with impaired renal function. Three patients (8.8\%) had ocular sequelae on discharge. ${ }^{9}$ Since the introduction of the use of IVIG in the treatment of SJS/TEN, there have been no studies looking specifically at the ocular outcomes. The differences in outcomes between the various trials with regard to the time to cicatrisation and mortality may have been due to higher doses and earlier treatment in trials that showed better outcome, inclusion and referral bias, and perhaps different brands of IVIG used. ${ }^{21}$

The major finding in our case series was the paucity of cases that had sight-threatening disease or ongoing active conjunctival and corneal disease after resolution of the disease. One patient did have sight-threatening ocular complications. This was the patient's presenting complaint and mirrored the overall severity of the disease. Other complications included pneumonitis requiring mechanical ventilation and severe neutropenia. All our patients had also received standard medical interventions for TEN such as topical corticosteroids, lubricants, antibiotics, and careful skin care. A comparison of our historical cohort and the IVIG-treated groups showed no difference in frequency of ocular complications and severity between those who received IVIG and those who did not. It is, however, notable that the two patients presenting with ocular complaints prior to the onset of cutaneous lesions appeared to have a more severe ocular course. There was however a trend towards increased ocular complications in the treatment group. This was however not statistically significant. This could 
Table 5 Summary comparing acute and long-term ocular complications in reported series of patients with TEN

\begin{tabular}{|c|c|c|c|c|c|c|c|c|c|}
\hline Year & Author & Age group & $\begin{array}{l}\text { Period of } \\
\text { study }\end{array}$ & $\begin{array}{l}\text { Type of } \\
\text { reaction }\end{array}$ & $\begin{array}{l}\text { Number } \\
\text { studied }\end{array}$ & $\begin{array}{l}\text { Number with } \\
\text { acute ocular } \\
\text { sequelae }\end{array}$ & $\begin{array}{l}\text { Number with } \\
\text { long-term ocular } \\
\text { sequelae }\end{array}$ & $\begin{array}{l}\text { Immunosuppressive } \\
\text { therapy }\end{array}$ & $\begin{array}{l}\text { Types of long-term } \\
\text { ocular sequelae }\end{array}$ \\
\hline 1967 & Lyell et al $l^{12}$ & $\begin{array}{l}\text { Adult and } \\
\text { paediatric }\end{array}$ & 1 year & TEN & 98 & $6(6.1 \%)$ & $1(1.0 \%)$ & Nil & Corneal scarring (1) \\
\hline 1984 & Westly et $a l^{13}$ & $\begin{array}{l}\text { Adult (6) and } \\
\text { paediatric (4) }\end{array}$ & 5 years & TEN & 10 & Unknown & $3(30.0 \%)$ & $\begin{array}{l}\text { Systemic corticosteroids } \\
\text { (7) }\end{array}$ & Corneal scarring (3) \\
\hline 1985 & $\begin{array}{l}\text { Ruiz- } \\
\text { Maldonado } \\
\text { et } a l^{14}\end{array}$ & Paediatric & 12 years & SJS/TEN & 60 & $\begin{array}{l}19(31.7 \%) \\
- \text { conjunctivitis } \\
3(5.0 \%) \\
\text { - corneal } \\
\text { ulcers }\end{array}$ & Unknown & Nil & Unknown \\
\hline 1986 & $\begin{array}{l}\text { Halebian } \\
\text { et al }{ }^{15}\end{array}$ & Adult & Unknown & TEN & 30 & Unknown & $6(20.0 \%)$ & $\begin{array}{l}\text { Systemic corticosteroids } \\
\text { (26) (Type and dose } \\
\text { unspecified) - high dose (15) }\end{array}$ & $\begin{array}{l}\text { Tear duct atrophy and sicca } \\
\text { syndrome }(3)^{*} \text { Symplepharons } \\
\text { (2) Ankylosymblepharons (1) } \\
\text { Sicca syndrome (1) }\end{array}$ \\
\hline 1987 & Revuz et $a l^{1}$ & $\begin{array}{l}\text { Adult (76) and } \\
\text { paediatric (11) }\end{array}$ & 12 years & SJS/TEN & 87 & $68(78.2 \%)$ & $\begin{array}{l}15(50.0 \%) \\
\text { (of } 30 \\
\text { systematically } \\
\text { followed-up) }\end{array}$ & Nil & $\begin{array}{l}\text { Sicca syndrome (13) } \\
\text { Neovascularisation, epithelial } \\
\text { proliferation of cornea and } \\
\text { visual impairment (3) }\end{array}$ \\
\hline 1989 & Prendiville $e t a l^{16}$ & Paediatric & 11 years & TEN & $\begin{array}{l}21 \\
- \text { SJS (14) } \\
- \text { TEN (7) }\end{array}$ & $\begin{array}{l}17(54.8 \%) \\
- \text { SJS }(13, \\
92.9 \%) \\
- \text { TEN } \\
(4,57.1 \%)\end{array}$ & $\begin{array}{l}4(19.0 \%) \\
- \text { SJS }(3,21.4 \%) \\
- \text { TEN }(1,14.3 \%)\end{array}$ & Nil & Symblepharon (2) Dry eyes (2) \\
\hline 1995 & $\begin{array}{l}\text { Kelemen III } \\
\text { et } \text { l }^{17}\end{array}$ & Adult & 12 years & TEN & 37 & $18(49.0 \%)$ & Nil & $\begin{array}{l}\text { Systemic corticosteroids } \\
\text { (Type and dose unspecified) } \\
-0-48 \mathrm{~h}(23)->48 \mathrm{~h}(14)\end{array}$ & Nil \\
\hline 1999 & Wong et $a l^{18}$ & Adult & 12 years & SJS/TEN & $\begin{array}{l}17 \\
- \text { SJS (10) } \\
- \text { TEN (7) }\end{array}$ & $\begin{array}{l}17(100.0 \%) \\
- \text { SJS }(10, \\
100.0 \%) \\
- \text { TEN } \\
(7,100.0 \%)\end{array}$ & $\begin{array}{l}3 \\
- \text { SJS }(0,0.0 \%) \\
- \text { TEN } \\
(3,42.9 \%)\end{array}$ & $\begin{array}{l}\text { Systemic corticosteroids } \\
\text { (prednisone } 0.5-1 \mathrm{mg} / \mathrm{kg} \\
\text { body weight for } 5-14 \text { days in } 5 \\
\text { SJS and } 0.5 \mathrm{mg} / \mathrm{kg} \text { body } \\
\text { weight for } 2 \text { days in } 1 \text { TEN) }\end{array}$ & $\begin{array}{l}\text { Symblepharon (1) Epiphora } \\
\text { from canalicular duct } \\
\text { obstruction (1) Entropion with } \\
\text { trichiasis (2) }\end{array}$ \\
\hline 2003 & Prins et $a l^{7}$ & $\begin{array}{l}\text { Adult (40) and } \\
\text { paediatric (8) }\end{array}$ & 3 years & TEN & 48 & Unknown & Nil & $\begin{array}{l}\text { High-dose IVIG (mean total } \\
\text { dose } 2.7 \mathrm{~g} / \mathrm{kg} \text { body weight) }\end{array}$ & Nil \\
\hline 2003 & Bachot $e t a l^{9}$ & $\begin{array}{l}\text { Adult (33) and } \\
\text { paediatric (1) }\end{array}$ & 2 years & $\begin{array}{l}\text { SJS/TEN } \\
\text { SJS-TEN }\end{array}$ & $\begin{array}{l}34-\text { SJS }(9) \\
- \text { SJS/TEN } \\
(5)-\text { TEN } \\
(20)\end{array}$ & Unknown & Unknown & $\begin{array}{l}\text { High-dose IVIG (mean total } \\
\text { dose } 2 \mathrm{~g} / \mathrm{kg} \text { body weight) }\end{array}$ & Unknown \\
\hline 2003 & Yip et al & Adult & 1 year & TEN & 10 & 9 & 1 & $\begin{array}{l}\text { High-dose IVIG } \\
\text { (mean total dose } 2 \mathrm{~g} / \mathrm{kg} \\
\text { body weight) }\end{array}$ & $\begin{array}{l}\text { Nonhealing epithelial defect } \\
\text { requiring amniotic membrane } \\
\text { graft, peripheral } \\
\text { vascularisation and corneal } \\
\text { scarring at } 18 \text { months (1) }\end{array}$ \\
\hline
\end{tabular}


perhaps be explained by a similar trend of reduction in mortality in the treatment group. Those surviving patients having had more severe systemic illness would increase the number of cases of more severe ocular involvement.

Our study has several weaknesses. First, the number of subjects was few. However, TEN is a relatively uncommon disease. This may be so because most physicians would have stopped possible putative drugs early upon the appearance of a drug eruption, avoiding progression to TEN. In the case of the historical cohort, there may have been a lower retrieval of patients from incorrect coding of medical records.

Second, ophthalmic evaluation would have been more complete had all patients with TEN been screened by an ophthalmologist for ocular involvement, rather than only those who were clinically suspected by the dermatologist or allergist-immunologist. This may have caused an underestimation of the ocular involvement, particularly in the historical group. Third, the exclusion of those who died could introduce bias. However their follow-up was short and incomplete due to their demise. Fourth, an estimate of the total body surface area involved by TEN and the time to cicatrisation would have been useful in assessing the effects of IVIG on cutaneous and ocular involvement in TEN. Finally, the long-term follow-up of the treatment group is at this time limited. A longer follow-up may demonstrate better ocular surface health after IVIG.

Several retrospective studies have shown that systemic corticosteroids are associated with increased mortality in TEN $^{13,15,17}$ with no effect on ocular outcomes. ${ }^{3}$ Case series of patients with TEN treated with cyclosporine, ${ }^{22}$ cyclophosphamide, ${ }^{23}$ and plasmapharesis ${ }^{24}$ as immunomodulatory agents have been reported. Although these reports showed some benefit on cutaneous outcomes, they did not report on the ocular sequelae. As such the role of immunomodulatory agents on ocular outcomes in TEN cannot be inferred. The only double-blind placebo-controlled trial to date in the management of TEN, using thalidomide ${ }^{25}$ was stopped because there was excessive mortality in the thalidomide group. Nonetheless, it did not appear to have any effect on the progression of skin detachment and ocular effects were not studied. Treatment modalities like IVIG and cyclosporin with both antiapoptotic and T-cell immunosuppressive properties, should be evaluated in the form of large multicentre prospective trials especially with regards to their effects both clinically and immunohistologically, on the skin and eye. Placebo-controlled trials in drug allergy would be difficult to carry out due to ethical issues given the life-threatening potential of these serious reactions.

\section{Conclusions}

Ocular involvement is common in East Asian patients with toxic epidermal necrolysis. Few have sightthreatening disease or ongoing conjunctival and corneal disease. High-dose intravenous immunoglobulins did not appear to reduce the severity of visually significant ocular complications, although our findings will need to be substantiated by larger prospective multicentre collaborative studies.

\section{Acknowledgements}

Financial support: Tan Tock Seng Hospital Small Projects Grant, Tan Tock Seng Hospital, Singapore. Grant-RI 02/08.

Proprietary interest: Nil.

\section{References}

1 Revuz J, Penso D, Roujeau JC, Guillaume JC, Payne CR, Wechsler $\mathrm{J}$ et al. Toxic epidermal necrolysis. Clinical findings and prognosis factors in 87 patients. Arch Dermatol 1987; 123: 1160-1165.

2 Schopf E, Stuhmer A, Rzany B, Victor N, Zentgraf R, Kapp JF. Toxic epidermal necrolysis and Stevens-Johnson syndrome. An epidemiologic study from West Germany. Arch Dermatol 1991; 127: 839-842.

3 Power WJ, Ghoraishi M, Merayo-Lloves J, Neves RA, Foster CS. Analysis of the acute ophthalmic manifestations of the erythema multiforme/Stevens-Johnson syndrome/toxic epidermal necrolysis disease spectrum. Ophthalmology 1995; 102: 1669-1676.

4 Pichler W, Yawalkar N, Schmid S, Helbling A. Pathogenesis of drug-induced exanthems. Allergy 2002; 57: 884-893.

5 Viard I, Wehrli P, Bullani R, Schneider P, Holler N, Salomon $\mathrm{D}$ et al. Inhibition of toxic epidermal necrolysis by blockade of CD95 with human intravenous immunoglobulin. Science 1998; 282: 490-493.

6 Stella M, Cassano P, Bollero D, Clemente A, Giorio G. Toxic epidermal necrolysis treated with intravenous high-dose immunoglobulins: our experience. Dermatology 2001; 203: 45-49.

7 Prins C, Kerdel FA, Padilla RS, Hunziker T, Chimenti S, Viard I et al. Treatment of toxic epidermal necrolysis with high-dose intravenous immunoglobulins: multicenter retrospective analysis of 48 consecutive cases. Arch Dermatol 2003; 139: 26-32.

8 Tristani-Firouzi P, Petersen MJ, Saffle JR, Morris SE, Zone JJ. Treatment of toxic epidermal necrolysis with intravenous immunoglobulin in children. J Am Acad Dermatol 2002; 47: 548-552.

9 Bachot N, Revuz J, Roujeau JC. Intravenous immunoglobulin treatment for Stevens-Johnson syndrome and toxic epidermal necrolysis: a prospective noncomparative study showing no benefit on mortality or progression. Arch Dermatol 2003; 139: 33-36.

10 Arstikaitis MJ. Ocular aftermath of Stevens-Johnson syndrome. Arch Ophthalmol 1973; 90: 376-379. 
11 Bastuji-Garin S, Rzany B, Stern RS, Shear NH, Naldi L, Roujeau JC. Clinical classification of cases of toxic epidermal necrolysis, Stevens-Johnson syndrome, and erythema multiforme. Arch Dermatol 1993; 129: 92-96.

12 Lyell A. A review of toxic epidermal necrolysis in Britain. $\mathrm{Br}$ J Dermatol 1967; 79: 662-671.

13 Westly ED, Wechsler HL. Toxic epidermal necrolysis. Granulocytic leukopenia as a prognostic indicator. Arch Dermatol 1984; 120: 721-726.

14 Ruiz-Maldonado R. Acute disseminated epidermal necrosis types 1,2, and 3: study of sixty cases. J Am Acad Dermatol 1985; 13: 623-635.

15 Halebian PH, Corder VJ, Madden MR, Finklestein JL, Shires GT. Improved burn center survival of patients with toxic epidermal necrolysis managed without corticosteroids. Ann Surg 1986; 204: 503-512.

16 Prendiville JS, Hebert AA, Greenwald MJ, Esterly NB. Management of Stevens-Johnson syndrome and toxic epidermal necrolysis in children. J Pediatr 1989; 115: 881-887.

17 Kelemen III JJ, Cioffi WG, McManus WF, Mason Jr AD, Pruitt Jr BA. Burn center care for patients with toxic epidermal necrolysis. J Am Coll Surg 1995; 180: 273-278.

18 Wong KC, Kennedy PJ, Lee S. Clinical manifestations and outcomes in 17 cases of Stevens-Johnson syndrome and toxic epidermal necrolysis. Australas J Dermatol 1999; 40: 131-134.

19 Roujeau JC, Phlippoteau C, Koso M, Wechsler J, Andre C, Binaghi $\mathrm{M}$ et al. Sjogren-like syndrome after drug-induced toxic epidermal necrolysis. Lancet 1985; 1: 609-611.

20 Revuz J, Roujeau JC, Guillaume JC, Penso D, Touraine R. Treatment of toxic epidermal necrolysis. Creteil's experience. Arch Dermatol 1987; 123: 1156-1158.

21 Bachot N, Roujeau JC. Intravenous immunoglobulins in the treatment of severe drug eruptions. Curr Opin Allg Clin Immunol 2003; 3: 269-274.

22 Arevalo JM, Lorente JA, Gonzalez-Herrada C, JimenezReyes J. Treatment of toxic epidermal necrolysis with cyclosporin A. J Trauma 2000; 48: 473-478.

23 Trautmann A, Klein CE, Kampgen E, Brocker EB. Severe bullous drug reactions treated successfully with cyclophosphamide. Br J Dermatol 1998; 139: 1127-1128.

24 Bamichas G, Natse T, Christidou F, Stangou M, Karagianni A, Koukourikos S et al. Plasma exchange in patients with toxic epidermal necrolysis. Ther Apher 2002; 6: 225-228.

25 Wolkenstein P, Latarjet J, Roujeau JC, Duguet C, Boudeau S, Vaillant $\mathrm{L}$ et al. Randomised comparison of thalidomide versus placebo in toxic epidermal necrolysis. Lancet 1998; 352: 1586-1589. 